\title{
Absolute vs Relative Indicator
}

National Cancer Institute

\section{Source}

National Cancer Institute. Absolute vs Relative Indicator. NCI Thesaurus. Code C45832.

An indicator that a measurement is reported as absolute or relative to some other

measurement. (caMAGE) 